\title{
Role of Alumni of the School of Pluralism to Maintaining Religious Harmony in North Sulawesi
}

\author{
Suzy Azeharie ${ }^{1 *}$, Wulan Purnama Sari ${ }^{2}$ \\ ${ }^{1}$ Faculty of Communication, Universitas Tarumanagara, Jakarta 11440, Indonesia \\ ${ }^{2}$ Faculty of Communication, Universitas Tarumanagara, Jakarta 11440, Indonesia \\ ${ }^{*}$ Corresponding author. Email: suzya@fikom.untar.ac.id
}

\begin{abstract}
As a multicultural country, the opportunities for clashes and conflicts in Indonesia are widely open. The plurality and heterogeneity of Indonesian society is reflected in multiple cultures, religions, and lifestyle diversity. In the national history of Indonesia, various inter-religion conflicts occurred in Poso in 1998 and Ambon in 1999 and others. There are uncountable casualties and material losses in the conflicts. Many conflicts with the religious flags have led Synod of Churches in North and Central Sulawesi to spearhead the Peace Love Movement as an interfaith movement. The Synod Am/SAG houses 13 other churches. The movement pioneer by the Synod Am/SAG later became a pioneer in building public awareness that despite our society is diverse, we are one nation. Therefore, it was initiated the School of Pluralism in 2014, the school that educates the interfaith youth through class encounter classes. It was held one week. This pluralism school is held annually. Based on the above background, the researchers are interested in examining the role of Pluralism School alumni in maintaining religious harmony in North Sulawesi.
\end{abstract}

\section{Keywords: Pluralism School, Interfaith Harmony, North Sulawesi}

\section{INTRODUCTION}

Indonesia as a multicultural country, the opportunities for clashes and conflicts in Indonesia are widely open. The plurality and heterogeneity of Indonesian society is reflected in the form of quite complex cultural, religious, and lifestyle diversity. For example, despite there are six major religions recognized by the government, i.e. Islam, Catholicism, Christianity, Buddhism, Hinduism and Confucianism, hundreds of traditional beliefs exist and develop in society. And even though the Javanese are the largest population, according to Sudadi, the Central Bureau of Statistics (BPS) in cooperation with the Institute of South Asian Studies mentions that there are around 633 ethnic groups obtained from ethnic and sub-ethnic groupings in Indonesia [1]. Data from BPS show that the largest population is Javanese with total number of 95.2 million people followed by Sundanese totaling 36.7 million people [2]. This makes Indonesian society both vertically and horizontally a country with the most plural society in the world after the United States and India.

During the New Order era, the diversity of ethnicity in society as mentioned at above was considered a threat to the achievement of national unity. Soedjatmiko stated in Abdullah that the New Order had put aside the ethnic differences because it was seen as an inhibiting factor for integration and therefore it was an obstacle to the development which was the only valid ideology for the New Order [3]
Differences in religion, tradition, and others are sources of community conflict. Religious conflicts generally occur due differences in concepts or practices carried out by religious adherents that deviate from the provisions stipulated by religious law. From the differences, the conflicts begin [4]. In general, according to Yunus, there are two cause of the religious conflicts. Firstly, it relates to a truth claim. There is a tendency for a person to try to justify his/her religious teachings despite he / she may not really understand the noble values contained in the religion he/she defends. It makes that person degrading other people who do not agree even despite they convert the same religion. This is due to the plurality of humans which causes the face of truth to appear different when it is interpreted.

The second factor that triggers the conflicts is the jihad doctrine. Despite religious teachings are doctrines, adherents are given the freedom to interpret the scriptural texts [4]. This freedom to interpret dogma frequently becomes the source of sectarian conflict in society.

Various religion conflicts have colored the history of the Indonesian nation subsequently. Among others these were the Poso conflict in 1998, the Ambon conflict in 1999, the Sunni and Shia conflict in East Java in 2006, the construction of the GKI in the Yasmin Housing Complex in Bogor. The number of casualties and material losses is uncountable.

The number of conflicts with the religious flag had led the Synod Am of Churches in North and Central Sulawesi Church to make a movement, i.e. the Love Peace Movement as an interfaith movement. The Synod Am of Churches in 
North and Central Sulawesi houses 13 other churches including the Christian Evangelical Church in Minahasa (GMIM), the Christian Evangelical Church in SangiheTalaud, the Christian Evangelical Church in Bolaang Mongondow, the Indonesian Protestant Church in Gorontalo, the Indonesian Protestant Church in Buol Toli Toli and others.

The movement pioneered by the Synod Am/SAG later became a pioneer in the building of public awareness that despite in diversity, the society is one nation. Therefore, in 2014 the initiation of the School of Pluralism, a school that educates the interfaith youth through class encounter classes, was initiated for one week.

This School of Pluralism is held annually. It opens three elementary classes and two advanced classes. Advanced class participants are graduates of the elementary class. Fifty participants attend each class with the same gender composition between men and women. The participants are Muslim, Christian, Hindu, Confucian and Buddhist youth (the interview with the resource persons in Manado on October 23, 2020)

In the class each participant learns what the teachings of Islam, Christianity, Buddhism, Confucianism and Hinduism are briefly. The concepts put forward in the school is peace in differences and differences in brotherhood

To organize this School of Pluralism, cooperation is carried out with other parties, for example with the Institute for Interfaith Dialogue in Indonesia or Interfidei which is headquartered in Yogyakarta, as well as with the Indonesian Journalists Association.

These alumni of the School of Pluralism are now scattered in Sulawesi, particularly in North Sulawesi. It is interesting to see whether and how the role of the alumni of the School of Pluralism in maintaining religious harmony in the province.

In maintaining the diversity and harmony, the communication aspect plays an important role. Because without communicating with various stakeholders, harmony will not be realized. Through communication process, the various problems that exist can be resolved.

From the above background, the researchers are interested in examining the roles of alumni of the School of Pluralism in maintaining religious harmony in North Sulawesi Province and the obstacles they encounter when maintaining religious harmony in North Sulawesi.

\subsection{Related Work}

Until right now, there is no research on the School of Pluralism in North Sulawesi. It likely occurs because this school remains new, i.e. in 2014 and it was stagnant again in 2019 due to the structure change at GMIM. However, researches on pluralism in Indonesian society has been carried out quite a lot. Among others, Made Saihu wrote about the Portrait of Religious Pluralism Education in Jembrana Bali in 2020. Saihu [7] had examined the process of integration between religion and culture through the model of religious and cultural education in Jembrana Bali.
Another research was conducted by Muhammad Aji Nugroho with the title of Urgency and Significance of Multicultural Islamic Education on the Complexity of Diversity in Indonesia [8]. This research aims to present religious expressions in accordance with their authentic sources, both in thought, action, and fellowship which is an expression that gives real goodness to life, is able to free humans from ignorance, poverty, enmity and backwardness. This research is a research library.

\subsection{Our Contribution}

The school of pluralism teaches interfaith youth about religious diversity and it is a new and brilliant idea initiated by the Peace Love Movement. After the school has been implemented for five years, the alumni are spread all over Sulawesi. So it is interesting to see how the role of these alumni in maintaining religious harmony in North Sulawesi. Researches on the School of Pluralism has never been conducted.

\subsection{Paper Structure}

This paper is systematically structured as follows: Firstly, it relates to the introduction to what the School of Pluralism is and the focus of this research is. Secondly, in the next section discusses the researches having been carried out by previous researchers and what contributions the researchers have made. Thirdly, it put in the research background and research methods. Finally, the paper discusses the research finding and discussion.

\section{BACKGROUND}

North Sulawesi is a province where the majority of the population is Christian and Islam is the second largest religion. Data from the Central Bureau of Statistics in 2010 show that the population is Christian totaling $63.60 \%$, Islam (30.9\%), Hindu (0.58\%) and Buddhist totaling 0.14\% [2]. According to DP Salim, Islam came to this province due to the influence of Gowa Tallo Kingdom in the 15-16th century while Buddhism was brought into the province due to trading activities during the Sriwijaya Kingdom era. Catholicism entered this province in the 16th century for Portuguese traders and Protestant Christianity developed around 1905 [14].

The people of North Sulawesi hold the value of Torang Samua Basudara or it means We are All Brothers. The philosophy contained in this value according to Manti in Rumondor and Tumiwa is openness, mutual respect, mutual help and help each other. Because in general the people of North Sulawesi work in agriculture, this value is usually applied when there are people who are working on their agricultural fields [15].

In addition, it is known the Sitou Timou Tumou Tou philosophy. The meaning of Sitou Timou Tumou Tou 
according to Priscila F. Rampengan is "Living People Bring Others to Life" [16]. According to Gabriele Weichart, the Governor of Vereenigde Oost-Indische Compagnie or VOC, Robertus Padtbrugge, signed an agreement with the walak head in 1679. Walak is a unit consisting of several villages. This means that according to Weichart, historically the Minahasa people have been accustomed to interacting with other nations and tribes for a long time [17].

One evidence about this statement is the acceptance of one of the Warlords of Pangeran Diponegoro, i.e. Kyai Modjo. He was exiled to the Minahasa land in 1828 with his 63 followers, and all of them were male and Muslim. Moreover, they married Minahasa women and have children in the area until now [18]. A similar history occurred to Tuanku Imam Bonjol, a great cleric who led the Bonjol War in West Sumatra. Tuanku Imam Bonjol was banished by the Dutch to the Lotta area, Pineleng SubDistrict around 1841. One of his Ambonese bodyguards, Apolos Minggu went with him, and the Ambonese bodyguard later married Mayoor Kakaskasen's daughter, Wilhelmina Parengkuan or Mency. Wilhelmina later became Muslim and changed her name to Yunansi. There are seven generations of this couple in 2020 .

According to Yosef Ikanubun, these families then establish a Muslim community in Lotta and spread in Pineleng SubDistrict [19].

However, it is human nature if more people come to their land, they will feel threatened. Minahasa people feel that they are the first to come to the land area and they fully control the resources. With the increasing number of immigrants from outside their land area to Minahasa Land, their ownership of the resources will be getting smaller and smaller.

On the other hand, religious doctrine has contributed to introducing the gaps of difference that exist vis-à-vis adherents of other religions. The above factors has triggered frictions in society. According to an interview with a woman activist at GMIM Deeby Momongan, this friction has become more evident in the last two decades in Minahasa. The friction also closely relates to the growth of religious fundamentalist groups and it has widened the gap. Therefore, Christian groups begin to distance themselves and create boundaries with Islamic groups and vice versa. From the research results conducted by the Synod Am/SAG of Churches in North Sulawesi, it reveals that the gap is growing and it deliberately bumps into existing differences which results in a widening of the gap. The seeds of conflicts, according to Momongan, are triggered, among others, the attitude of Christian groups who tend to feel like the majority in the region. The Christian groups also tend to treat other religious groups relatively unfairly. For example they do not allow the establishment of a house of worship for another religion in one area.

According to the research, the escalation of conflicts has occurred in the last two decades. The reason is partly due to differences in physical appearance among religious communities. In the past, there were no striking differences between Muslims and Christians. However, with awareness of Muslim women to follow religious orders and wear hijab, there is a tendency for Muslim groups to distance themselves from associating with Christian groups that were very close to each other previously.

There are a number of conflicts with the religious flags, and it has made the Synod Am/SAG of Churches in North and Central Sulawesi establishing a movement, i.e. the Peace Love Movement as an interfaith movement. The Synod $\mathrm{Am} / \mathrm{SAG}$ of Churches in North and Central Sulawesi houses 13 other churches including the Christian Evangelical Church in Minahasa (GMIM), the Christian Evangelical Church in Sangihe-Talaud, the Christian Evangelical Church in Bolaang Mongondow, the Indonesian Protestant Church in Gorontalo, the Indonesian Protestant Church in Buol Toli Toli and others.

Therefore, it was initiated to establish the School of Pluralism in 2014, a school that educates the interfaith youth through classes that last for one week.

This School of Pluralism is held every year by opening three elementary classes and two advanced classes. The advanced class participants are graduates of the elementary classes. There are 50 participants in each class with the same gender composition between men and women and they come from young Muslims, Christians, Hindus, Kong $\mathrm{Hu} \mathrm{Chu}$ and Buddhists.

In the class each participant learns briefly about the basic philosophies of Islam, Christianity, Buddhism, Confucianism and Hinduism. The concept that the school put forward is peace in differences and differences in brotherhood.

To organize this School of Pluralism, it makes collaboration with other parties, for example with the Institute for Interfaith Dialogue in Indonesia or Interfidei which is headquartered in Yogyakarta and the Indonesian Journalists Association.

\section{METHODS}

This research uses a qualitative approach. According to Bogdan and Taylor in Lexy J. Moleong, the qualitative methodology is a research procedure that produces descriptive data in a kind of written or spoken words from one's observable behavior [10].

Muri Yusuf has explained that the qualitative research is a research method to find meaning, understanding, to understand of a phenomenon, incident or human life that is directly or indirectly involved [11].

Mohammad Nazir explained the descriptive method as a method of examining a group of people, an object, condition, thought system or event in the present [12]. The research method used in this research is a case study. [11]. Robert K. Yin defines a case study in general as a research strategy. Which is suitable for answering research questions regarding how or why if the researcher has only a few opportunities to control the events to be investigated and the research focus on current phenomena [13]. 


\section{FINDINGS AND DISCUSSIONS}

According to one of the sources of the alumni from the School of Pluralism in 2014, Rusli Umar as an alumni of the school has joned a WhatsApp conversation group called the Peaceful Love Movement. However, in line with the developments, the WA group members not only consist of alumni of the School of Pluralism but also journalists from the Indonesian Journalists Association, field activists and LGBT as well.

Through the WA conversation group, according to Rusli Umar, a network was built to establish interfaith communication. If there are data or facts obtained, they are divided into groups. Moreover, each member of the groups independently give their opinion dewspite the opinion is subjective. Furthermore, there is a process of clarification in which the members provide information.

For example, in this clarification, according to Rusli Umar as an ANSOR activist, He said that there were many members of the NU Banser who had high-mobility jobs, such as motorbike taxi drivers or traveling traders. Therefore, if there is a potential conflict, Rusli will ask the NU Banser members who are within a radius of $5-10$ kilometers from the location of the conflict on how the process of the incident has occur. Furthermore, the data that Rusli obtained in the field were uploaded to the WA group. Banser is an organizational instrument of the Ansor Youth Movement which functions as a safeguard for the social programs of the Ansor Youth Movement. Banser, founded in 1937, is an autonomous body from Nahdlatul Ulama Another example of potential conflict occurs in the North Minahasa area. In this area a mosque would be built in last year. However, there was issue that stated that the Christian community rejected this mosque construction. Through the communication network of the Peace Love Movement, it was known that what actually happened was not a rejection of the mosque construction but the North Minahasa people required the legality of the construction. It was because before the mosque construction was held it was a meeting hall. After all legal matters were resolved and clear, the mosque construction went on. However, the issue has become a hot ball that Christians rejected the mosque construction. In response, all alumni of The School of Pluralism School and the WA group members tried to find clear information and data. Furthermore, they went to the North Minahasa area to meet key figures in the area. Currently, according to him, the mosque has added a second story.

Another example cited by the source was the arrival of Fahri Hamzah, a politician known for his controversial remarks in Manado in May 2017. Thousands of people, including the Chairman of the Minahasa Adat, wearing Kabasaran clothes, were waiting for the arrival of Hamzah at Sam Ratulangie Airport to refuse his arrival. This was because he was worried that he would divide society. Hamzah frequently made disturbing statements and an intolerant attitude. Finally, Hamzah, who was scheduled to visit for three days, only arrived a few hours and then immediately returned to Greater Jakarta (20).
According to one resource person, Yessy Sentrum, with the entry of journalists into the WA conversation group for the Peace Love Movement, there are many benefits that can be obtained. For example, if a group of alumni feels that their lines of communication with executives are constrained, they use the hands of journalists to convey the issues they are facing through the writing of the journalists.

Together with the Indonesian Journalists Association, the Peace Love Group frequently holds face-to-face discussions to exchange ideas and discuss issues of potential conflicts in North Sulawesi Province. This discussion activity takes place once a month or twice a month depending on the issues and according to mutual agreement. Furthermore, the results of this discussion are summarized and then the journalists will be published in the information media. Therefore, the public understand the situation in the field. In addition to actively discussing in the conversation groups, the alumni of the School of Pluralism also hold discussion activities with students from the Christian University of Indonesia in Manado, Manado State Christian Institute and the Manado State Islamic Institute. According to one resource person, Yessy Sentrum, the discussion aims to provide an understanding to the younger generation about the nature of tolerance. Therefore, when these students graduate and give sermons to congregations in churches and mosques, they will continue the messages of tolerance for differences.

In addition to conducting discussions, according to the source, various activities are carried out that can raise public awareness. For example, when a bombing took place on Christmas Eve at a church in Samarinda in 2016, the alumni of the School of Pluralism held the Thousand Candles Movement lighting 1000 candles at the GMIM Sentrum church in Manado City. On that occasion, people who came from various elements, across religions, beliefs and cultures gathered together to pray for the victims and hope that such an event would not happen again. With the response and wide news coverage of the mass media, the speakers expected that the burning of the 1000 candles could inspire the feeling of Minahasa people to maintain harmony and tolerance. Moreover, alumni become community leaders or opinion leaders whose words and actions tend to be followed by the community, according to the patron-client pattern in the culture of the community.

Alumni of the School of Pluralism are also active in proclaiming the beauty of differences. For example, when in 2019 the Indonesian Muslim Arts and Culture Institute in North Sulawesi was holding an Interfaith Festival at the North Sulawesi Regional Parliament Building, some alumni of the School of Pluralism who were non-Muslim took the stage to pay tribute to Prophet Muhammad SAW but they used ecclesiastical tunes. This activity received wide news coverage from the mass media. The message that alumni want to convey is to respect each other despite they have different beliefs.

From interviews with the informants, it is known that the main obstacle the alumni encounter in maintaining religious harmony lies outside their non-formal organizations. Particularly in the attitude of the government it is considered very elitist because the government is trapped 
only in the process of reporting provided by the official bodies of the government such as the Forum for Religious Harmony (FKUB). According to the source, FKUB does not provide an objectivity assessment of the facts in the field. According to the alumni, figures in FKUB do not have roots at the grassroots level and therefore, the facts of what happened in the field between religious communities cannot be known in depth. Furthremore, it is considered that the figures in FKUB are elitist. When from the viewpoint of the government, the bureaucratic governance structure makes the government only trapped in receiving reports from FKUB without wanting to explore social facts that actually occur in society.

Another obstacle is if the Peace Love Movement pioneered by GMIM undergoes a change in the organizational structure, new committee members enter, they will give a new color to the movement which is not necessarily the same as the previous color. This will affect the mission and solidity of this movement. An example was the departure of Deeby Momongan from the GMIM organizational structure and a new committee member replaced her. In fact, Deeby Momongan, according to resource persons Rusli Umar and Yessy Sentrum, was a midwife who gave birth to the Peace Love School. As a result, the School of Pluralism had been hampered and stopped since 2019.

\section{CONCLUSIONS}

The Peace Love Movement, which began the establishment of the School of Pluralism in North Sulawesi, was an activity initiated by The Synod A of The Christian Evangelical Church in Minahasa in 2014. The Peace Love Movement was established on the basis of the concern that there are the increasing number of conflicts in society that carry religious flags and this escalates in the last two decades. This school of pluralism is held annually. It opens three elementary classes and two advanced classes. The advanced class participants are graduates of elementary class. There are 50 participants in each class with the same gender composition between men and women. The participants come from young Muslims, Christians, Hindus, Kong $\mathrm{Hu} \mathrm{Chu}$ and Buddhists.

In the class each participant learns briefly to know what the teachings of Islam, Christianity, Buddhism, Confucianism and Hinduism are. The concept put forward is peace in differences and differences in brotherhood.

In present, these school graduates join a WhatsApp conversation group called the Peace Love Movement. With the current developments, however, the WA group members not only come from the graduates of the School of Pluralism but also journalists of the Indonesian Journalists Association, field activists and LGBT.

Through the WA conversation group a network is built to establish interfaith communication. If there are data or facts the group have obtained, these will be shared to the group members. Moreover, each member of the group can give their opinion independently despite the opinion is subjective. Furthermore, there is a process of clarification in which the members provide information. Some cases have the potential to cause interfaith friction. For example, the issue of Christian community groups not allowing the construction of a mosque in the North Minahasa area can be resolved through cooperation in this network.

Alumni actively conduct discussion activities with students from various campuses in North Sulawesi, such as students from Christian University of Indonesian in Manado, Manado State Christian Institute (IAKN) and the State Islamic Institute of Manado. The discussion aims to provide an understanding to the younger generation about the nature of tolerance. Therefore, when these students graduate and give sermons to their congregation, they will continue the message of tolerance for differences.

As the Synod Am of Minahasa Christian Evangelical Churches (GMIM) establishes the School of Pluralism, it gets influence from the change of the organizational structure in the Synod Am. New people will enter and their soul and spirit are not necessarily in line with the alumni of the School of Pluralism. It also occurs to the new GMIM management right now, and it has stopped holding the School of Pularism since 2019.

The suggestion that the researchers can convey is that this School of Pluralism will become a permanent activity for the Synod Am of Christian Evangelical Church in Minahasa whoever will occupy the committee. The escalation of sectarian conflicts in society is increasing and so this activity must continue to be held. It will become breakthroughs for the interfaith young generation so that they can learn from an early age to have tolerance for differences.

The local government should also empower these alumni as one of the front guards in maintaining religious harmony in North Sulawesi Province. Not many provinces in the country have school alumni about pluralism. Threfore, the alumni spread across North Sulawesi Province must be embraced, their roles are strengthened and empowered. They will listen from various sources in the community and it is not only from sources supported by the Regional Government.

\section{ACKNOWLEDGMENT}

Deep gratitude is conveyed to the three speakers who took the time to meet and be interviewed both in Lawalaan and in Manado City. Thank you to Deeby Momongan, Rusli Umar and Yessy Sentrum. Without the kindness of the three of you, not a single letter from this research could have been written.

\section{REFERENCES}

[1] A.J. Pitoyo, H.Triwahyudi, Dinamika Perkembangan Etnis di Indonesia Dalam Konteks Konteks Persatuan Negara, Jurnal Populasi Vol 25, No. 1, UGM, Yogyakarta,2017,p.65.file:///C:/Users/ASUS/Download s/32416-76796-1-PB.pdf. 
[2] Biro Pusat Statistik, Hasil Sensus Penduduk 2010. BPS, Jakarta, 2010, pp. 8

[3] I. Abdullah, Tantangan Multikulturalisme Dalam Pembangunan. Jurnal Anthropologi dan Sosial Budaya Etnovisi Vol, II, No. 1, UGM. Yogyakarta, 2006, pp.14. https://d1wqtxts1xzle7.cloudfront.net/40395074/Etnovi si_Vol_II_No_1_April_2006.pdf?1448538868=\&res ponse-contentdisposition=inline\%3B+filename\%3DEtnovisi_Vol_II_ No_1_April_2006.pdf

[4] F.M. Junus, Konflik Agama di Indonesia Problem dan Solusi Pemecahannya, Substantia, Volume 16 Nomor 2, Oktober, 2014, pp. 217 - 221.file:///C:/Users/ ASUS/Downloads/4930-10669-1-SM\%

[5] U. Inayatul, A.A. Anshori. Multikultural Sebagai Resolusi Konflik Agama di Indonesia,Fikrah: Jurnal Ilmu Aqidah dan Studi Keagamaan, 2016. DOI: https://doi.org/10.21043/fikrah.v4i1.1663.

[6] R.Trianingsih. Pendidikan dalam Proses Kebudayaan yang Multikultural di Indonesia, Jurnal Tarbiyatuna, Vol 1, No.1, Banyuwangi, 2017 http://ejournal.iaiibrahimy. ac.id/index.php/tarbiyatuna/article/view/70file://C:/Use rs/ASUS/Downloads/70-13-218-1-10-20171001.pdf.

[7]AM. Saihu, Potret Pendidikan Pluralisme Agama di Jembrana Bali, Deepublish, Curup 2020, pp. 5-17.

[8] M.A. Nugroho, Urgensi dan Signigfikansi Pendidikan Islam Multikultural Terhadap Kompleksitas Keberagaman di Indonesia. Journal of Islamic Culture and Education, Attarbiyah, Vol. I No 2, Desember, pp. 179-210. DOI: 10.18326/attarbiyah.v1i2.179-210

[9] D. Nugraha, Urgensi Pendidikan Multikultural di Indonesia, Jurnal Pendidikan pancasila dan Kewarganegaraan, Tanjungpura, 2020.

[10] L.J. Moleong, Metodelogi Penelitian Kualitatif (Ed. Revisi). PT. Remaja Rosdakarya, 2012 Bandung, pp. 4.

[11] A.M. Yusuf, Metode Penelitian Kuantitatif, Kualitatif \& Penelitian Gabungan, Prenada Media, Deeplish, Jakarta, 2014, pp : 328.

[12] M. Nazir, Metode Penelitian, Ghalia Indonesia, Bogor, 2011, pp.54 - 339.

[13] R.K. Yin, Case Study Research design and Methods, SAGE Publications, 3 rd edition, New York, 2003.

[14] D.P.Salim, Politik Pendidikan Agama dan perubahan Prilaku di Sulawesi Utara, dalam Khazanah
Islam, Perjumpaan Kajian dengan Ilmu Sosialoleh Ahmad Rajafi et.al, Deepublish, 2018, pp. 56-58.

[15] P. Rumondor dan A.J.Tumiwa, Kebiasaan yang Menjadi Hukum Adat Lintas Keluarga (Studi Kasus Setiap Kunjungan Hari Raya Besar Antar Umat Beragama di Sulawesi Utara), Jurnal Al Mabhats, LhokSeumawe, 2019.

[16] P.F. Rampengan, Sitou Timou Tumou Tou Sebagai Wujud Misi Gereja, Jurnal Tumuo Tou, Vol.2, No.2. Manado, 2015, pp. 1.

[17] G. Weichart, Identitas Minahasa: Sebuah Praktik Kuliner. Jurnal Anthropologi Indonesia, No.74, Universitas Indonesia Jakarta, pp. 60-61.

[18] S. Azeharie, S. Paramita, W. Purnama Sari, Studi Budaya Nonmaterial Warga Jaton, Jurnal, ASPIKOM No. 3, Ed 6, Jakarta, 2019.

[19] Liputan6. https://www.liputan6.com/regional/read/ 2519213/kisah-tuanku-imam-bonjol-dan-pengawalsetianya-di-minahasa).

[20] Kompas.com14 Mei 2017, https://ebooks.gramedia. com/newspapers/kompas/pagi-14-may-2017. 